\title{
Morenia ocellata (Duméril and Bibron 1835) - Burmese Eyed Turtle
}

\author{
INDRANEIL DAS ${ }^{1}$ \\ ${ }^{1}$ Institute of Biodiversity and Environmental Conservation, \\ Universiti Malaysia Sarawak, 94300 Kota Samarahan, Sarawak, Malaysia \\ [idas@ibec.unimas.my]
}

SuMmary. - The Burmese eyed turtle, Morenia ocellata (Family Geoemydidae), is a small aquatic turtle (carapace length to $239 \mathrm{~mm}$ ), restricted to south and northeast Myanmar (Burma) and possibly, southwestern Yunnan in China. The species is still common in the Yangon (Rangoon) area, where large numbers may be seen in temple tanks. Typical habitat comprises paddy fields, streams, ponds, and slow-flowing portions of rivers. Nesting takes place between September and April, and clutch size varies from 5-8 to 10-15 eggs. Early 19th century literature accounts mention their exploitation, presumably for food by local people, and international food trade now occurs from Myanmar to China, but the overall status of the species throughout its range is unknown.

Distribution. - China (?), Myanmar. Distributed in southern and northeastern Myanmar and possibly southwestern Yunnan in China.

Synonymy. - Emys ocellata Duméril and Bibron 1835, Batagur (Kachuga) ocellata, Batagur (Morenia) ocellata, Clemmys ocellata, Morenia ocellata, Emys berdmorei Blyth 1859, Batagur berdmorei, Batagur berdmorii, Kachuga berdmorei, Morenia berdmorei.

SUBSPECIES. - None recognized.

STATUS. - IUCN 2010 Red List: Vulnerable (A1cd+2cd) (assessed 2000); CITES: Appendix I;

US ESA: Endangered.

Taxonomy. - This species was first described as Emys ocellata by Duméril and Bibron (1835), the specific name being an allusion to the bold, dark-centered ocellus (= small eye) on each of the vertebral and costal scutes. Subsequently, it was reallocated to several other genera, including Batagur (Gray 1856), Kachuga (Gray 1869), and Clemmys (Strauch
1862). Emys berdmorei Blyth 1859 is a synonym; see Anderson (1879) for discussion.

Anderson (1879), in the best extant morphological description of both species of Morenia, considered this taxon to be a subgenus of Batagur. Boulenger (1889) raised Morenia to the status of a full genus, and this decision has prevailed.

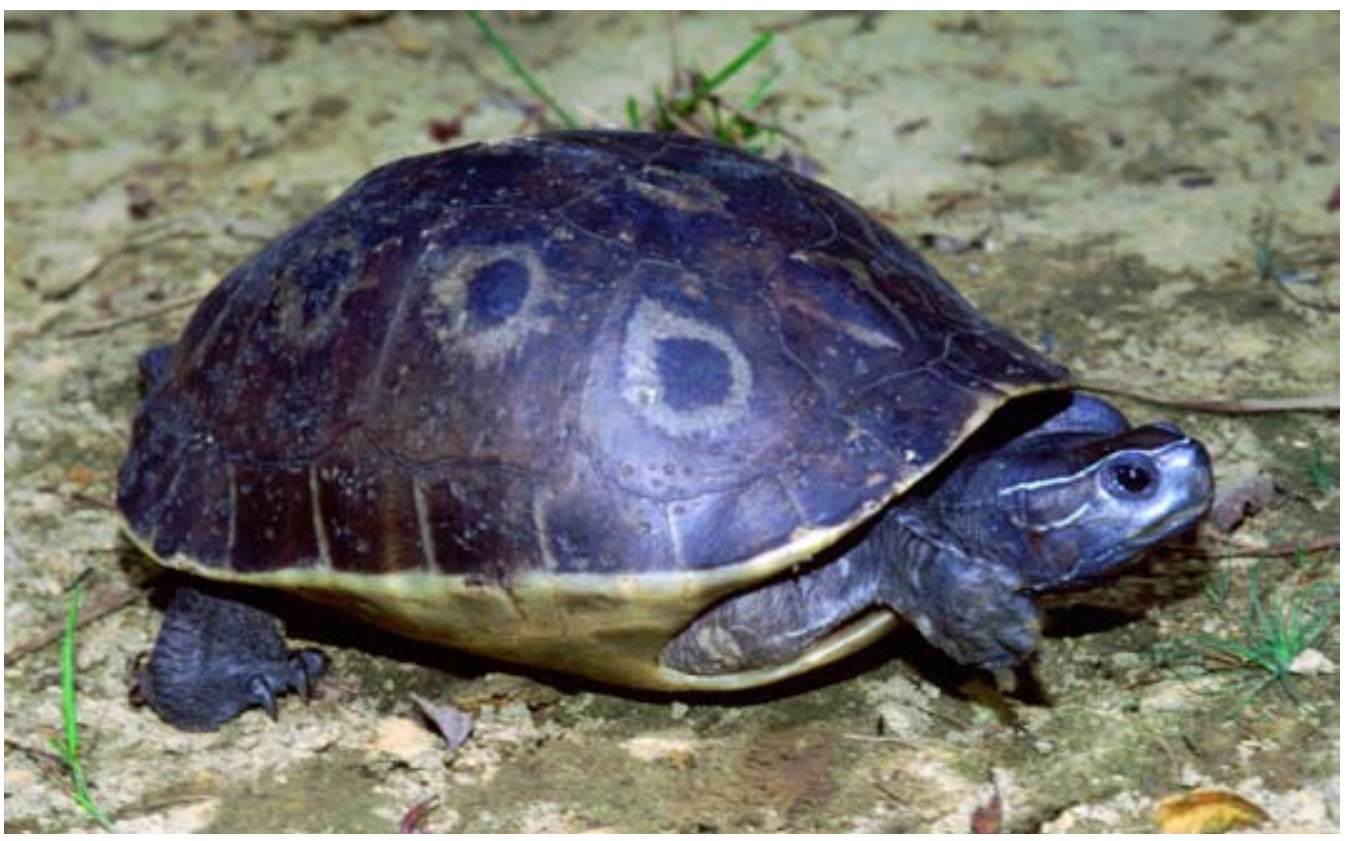

Figure 1. Morenia ocellata, adult female from Yangon, Myanmar. Photo by Indraneil Das. 


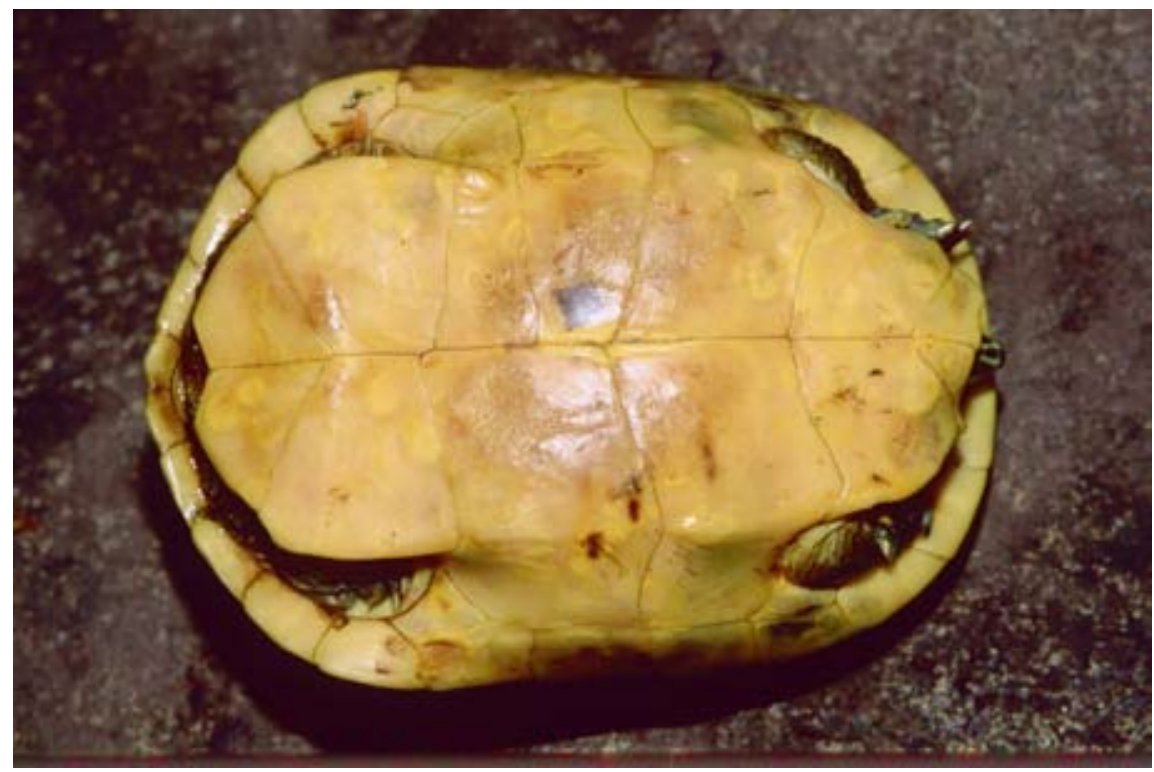

Figure 2. Morenia ocellata, adult female from Yangon, Myanmar; same as Fig. 1. Photo by Indraneil Das.

Nonetheless, as Smith (1931) has observed, the type locality ("Bengale") is definitely in error, in that this species has never been found in either West Bengal or Bangladesh, which constituted the British Indian Province of Bengal up to the early 20 th century.

No subspecies have been described and geographic variation has not been documented. Its closest relative is its only congener, Morenia petersi, from northeastern India and Bangladesh.

Description. - The carapace is markedly domed with strong vertebral tuberculations in young specimens. The carapace becomes relatively lower and less tuberculated in adults. Shallow concavities are present on each side of the median ridge of vertebral 1 , and above marginals 8-10 on each side. The nuchal scute is long and narrow in external aspect, its width only about $25 \%$ of the width of the first marginal scute; much shorter and with posteriorly converging sides in ventral aspect. The rim of the shell is smooth, lacking serrations.

The plastron is long, with a slight keel evident where the bridge meets the plastron on each side, except in large females. Anteriorly, the plastron is truncate; posteriorly, an angular anal notch is present.

The snout is short and somewhat pointed, and the margins of the jaws are finely serrated. The upper jaw is anteriorly bicuspid, and a symphysial hook is present on the lower jaw. A single enlarged scale covers the crown of the head, and there is a single large scale behind each eye. There is a series of very small scales behind the angle of the jaw, and a pair of mental glands is present. Very small, rounded, blackish papillae are present on the upper surface of the neck.

The carapace is olive, dark brown or gray-black, with a dark-centered, dark-bordered, yellow ocellus on each costal and vertebral scute. The ocelli are most prominent in the young. The plastron is unpatterned yellow, of very variable light to dark shade. The head is olive or dark gray-brown, with a yellow stripe from the tip of snout, over the orbit, to the neck, and a second stripe of the same color from the posterior corner of the orbit to the neck. The skin of the neck is pale brown, becoming light gray posteriorly. The limbs are olive or brown.

The bony shell has a neural bone configuration that includes an elongate tetragonal neural 1 , followed by six consistently broad but posteriorly shortened elements in the form of hexagons with the short sides adjacent to the anterior face. Two suprapygals are present, the anterior one being narrow and pedestal-shaped and the posterior one very broadly hexagonal, the extreme tips contacting the penultimate peripheral bones. There is no contact between left and right pleural bones.

Shell buttressing is minimal, with the axillary and inguinal buttresses reaching only slightly higher than the pleuro-peripheral suture line. The bridge is long and completely rigid. The plastron has the entoplastron lying anterior to the humero-pectoral suture.

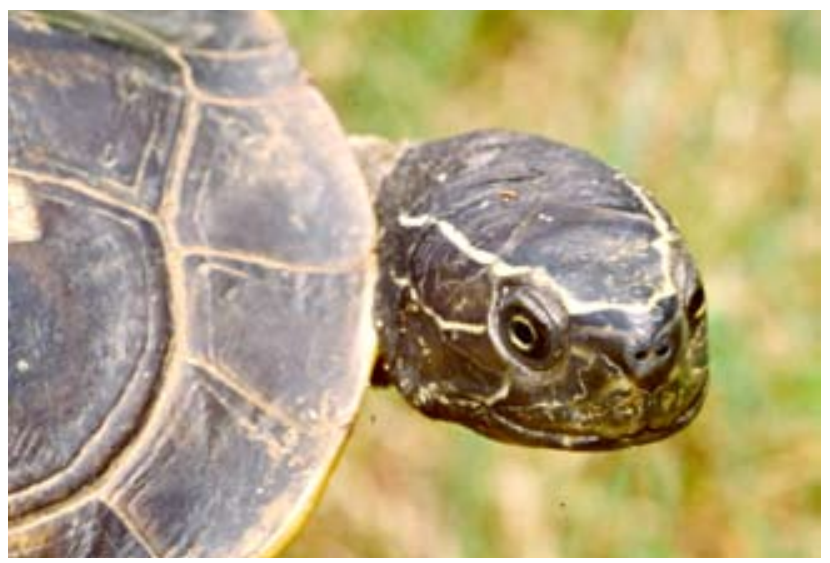

Figure 3. Morenia ocellata, adult male from Pyin Oo Lwin, Mandalay Division, Myanmar. Photo by George R. Zug, courtesy of Division of Amphibians and Reptiles, NMNH-Smithsonian. 


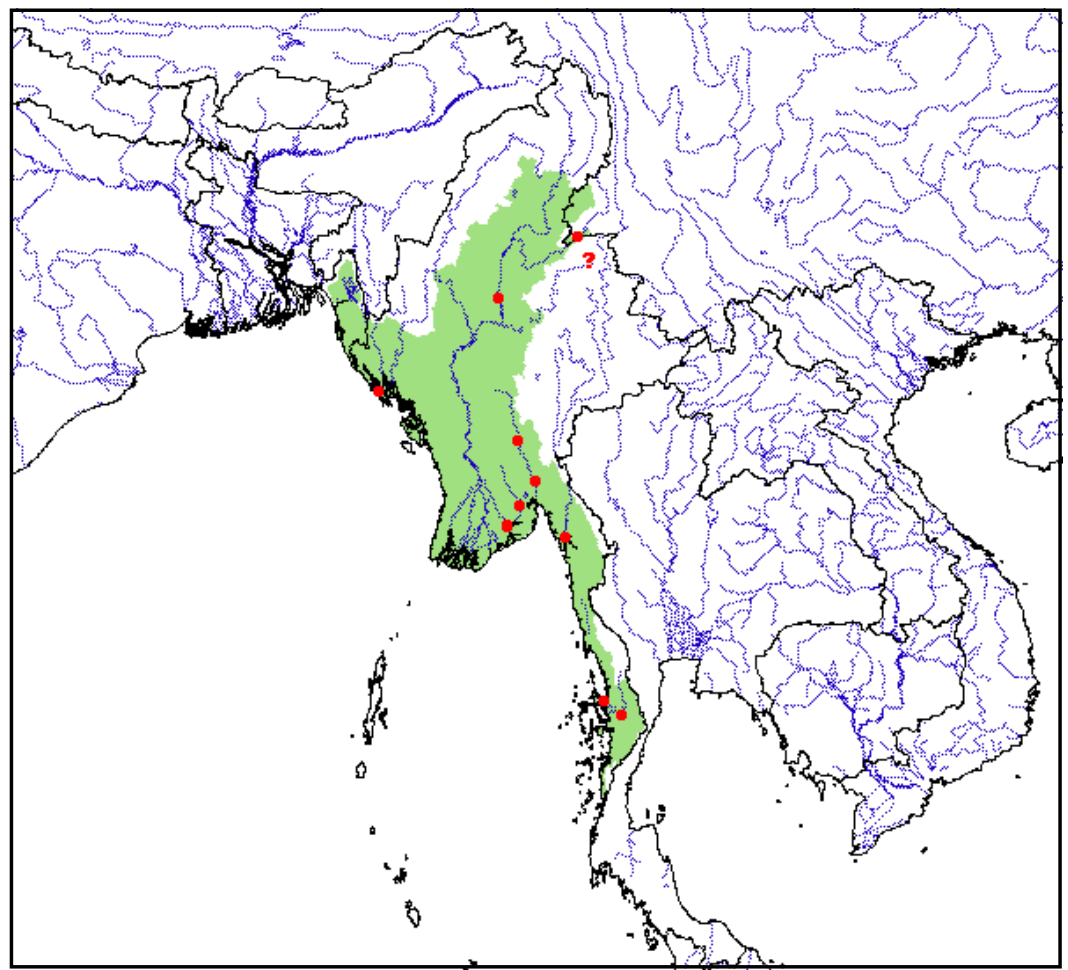

Figure 4. Distribution of Morenia ocellata in Myanmar and possibly Yunnan, China. Red points = museum and literature occurrence records based on Iverson (1992) plus more recent and author's data; green shading = projected distribution based on GIS-defined hydrologic unit compartments (HUCs) constructed around verified localities and then adding HUCs that connect known point localities in the same watershed or physiographic region, and similar habitats and elevations as verified HUCs (Buhlmann et al. 2009), and adjusted based on author's data.

The skull is noteworthy for the rather small, short supraoccipital crest, the vertically elongate premaxillae that penetrate into the nasal opening, and the extraordinarily developed jaw surfaces, with extensive secondary palate and complex pattern of ridges (some smooth and some nodose).

In terms of sexual dimorphism, males have a slight plastral concavity, and modestly enlarged tails, and they are considerably smaller than adult females. The latter may reach a straight carapace length (CL) of $239 \mathrm{~mm}$ (Platt et al. 2005), whereas adult males are generally only $135-150$ $\mathrm{mm}$ CL. Furthermore, as Anderson (1879) pointed out, even bony shells in the latter size range may be sexed by the presence of widely open intercostal fontanelles only in females, indicating potential capacity for further growth. The males

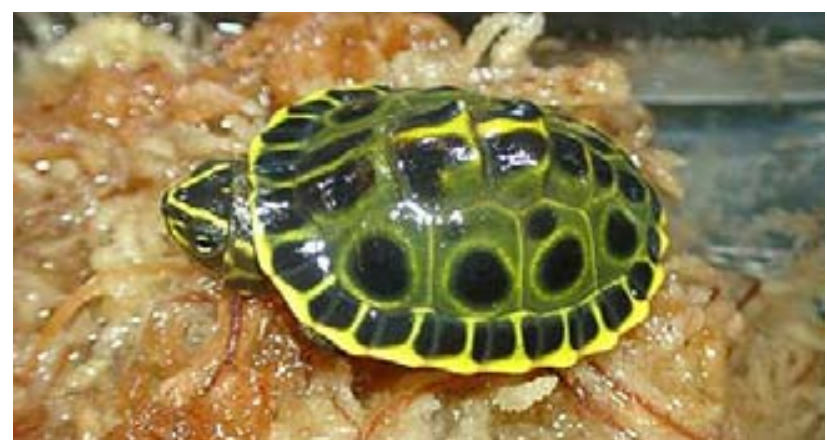

Figure 5. Morenia ocellata, hatchling of unknown provenance. Photo by Paul Reef at www.photobucket.com. are less domed than the females, and tend to be narrower, the shell having almost straight, posteriorly diverging sides.

The karyotype is unknown, and phylogeographic studies are not known to have been carried out. The species is phylogenetically distinctive; weak molecular support has been shown for a relationship to Orlitia, Malayemys, and the Batagur-Pangshura-Hardella-Geoclemys group(Spinks et al. 2004).

When compared to M.petersi, M. ocellata is characterized by a shorter snout and neck, an olive-brown carapace, a larger adult size (to $220 \mathrm{~mm}$ ), a more arched form of the shell, a relatively narrow posterior plastral lobe, and the long and narrow nuchal scute. Moreover, the first marginal is much broader than the sixth and the axillary makes broad contact with marginal 4 and scant contact with marginal 5 .

Distribution. - The Burmese eyed turtle has generally been thought to be restricted to southern Myanmar (Burma), all earlier known localities being in the plains, especially along the coast and along the lower reaches of the Ayeyarwady (Irawaddy) River and other smaller rivers within its flood plains. More recently, the species has also been reported to occur sparsely in upland Myanmar (Platt et al. 2005; Kuchling et al. 2006).

The type locality of the species, reportedly "Bengale" (= Bengal; either the state of West Bengal in India, or Bangladesh, which together constituted the Bengal Province of British India) is erroneous (see Iverson 1992). Smith (1931) wrote, "it is now definitely established that the true ocellata 


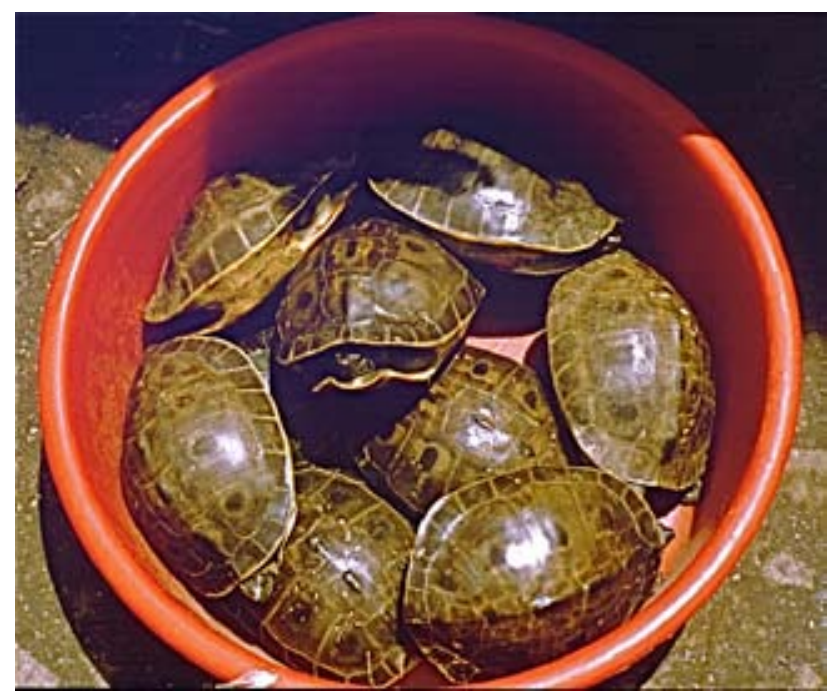

Figure 6. Morenia ocellata, adults for sale in food market in Ruili, Yunnan, China. Photo by Gerald Kuchling.

is the Burmese species and that it did not come from Bengal, where ocellata is unknown".

The species has been reported from markets of southwestern Yunnan Province, southern China (Kuchling 1995), and was reportedly collected locally, or from adjacent regions of upper Myanmar. Kuchling (1995) found local people in Mandalay describing turtles that were probably Morenia, and found indications that the species may be found upriver as far as Bhamo and beyond. About $50 \mathrm{~km}$ southeast of Bhamo, and across the Chinese border into Yunnan, is the town of Ruili, which lies on a major tributary of the Ayeyarwady River, of which the Chinese section is called the Longshuan Jiang, and the Burmese section is called the Schweli. In the Ruili fish and wildlife markets, Kuchling (1995) found $M$. ocellata to be the turtle species most commonly offered ( 81 specimens seen). In that the turtles were alive, unabraded, defecated copiously in the holding bags or in the water, and were brought into the market each morning, one by one, by people delivering live fish, the circumstantial evidence seems extremely strong that the turtles were both locally caught and locally abundant.

Habitat and Ecology. - Virtually nothing is known of the natural history of the species. According to Anderson (1879) and Smith (1931), it is aquatic and herbivorous. Theobald's (1868) data indicated that the turtle inhabits inundated plains in lower Myanmar, which on drying up during the summer months, are covered with thick grass. Maung and Ko Ko (2002) reported the species to inhabit paddy fields, streams, ponds, slow-flowing parts of rivers, and to nest between September and April (the dry season in Myanmar), when clutches of 5-8 eggs are laid. Thorbjarnarson et al. (2000) noted reports of clutch sizes of 10-15 eggs.

Population Status. - In the mid-19th century, the species was reported to be "extremely abundant" in the Pegu (Bago) and Tenasserim areas, where large numbers were caught by the locals (Theobald 1868). Large numbers continue to be harvested for food at present (Platt et al. 2000). Frazier
(1989) found it to be the most abundant of all turtles in the Yangon area, present in every temple pond "in hundreds; if not in thousands." However, these probably represent animals caught from localities throughout the range of the species in Myanmar by pilgrims, and the present status in the wild is unknown.

Threats to Survival. - These turtles were traditionally caught in large numbers, presumably for food, by the Burmese during March or April, by setting the grasses of the dry plains on fire (Theobald 1868). The great numbers of individuals still brought to temples in Yangon must also constitute a significant drain upon wild populations. As with most Myanmar turtle species, the international pet trade has traditionally been negligible (Pritchard 1979), although this appears to have changed since the late 1990s, and some numbers are offered for sale in aquarium and pet shops in Yangon (pers. obs.). Local consumption has also been reported in recent years from western and southern parts of Myanmar (Thorbjarnarson et al. 2000; Platt et al. 2001), and international trade for food consumption occurs from Myanmar to China (Kuchling 1995, Cheung and Dudgeon 2006).

Conservation Measures Taken. - The species is listed under Appendix I of CITES and as Endangered by the US Endangered Species Act.It is listed as Vulnerable on the IUCN Red List (www.iucnredlist.org). The species is included in Schedule I of the Bangladesh Wildlife (Preservation) Act of 1974 , even though the species does not occur in that country (Das 1989). In Myanmar, it is protected under the Myanmar Wildlife Law (1994), as well as under Myanmar Fisheries Law (1993) (see Maung and Ko Ko 2002).

Conservation Measures Proposed. - Studies on its biology, population status, distribution, and exploitation are required before specific conservation measures can be considered. It appears likely that the long-term inclusion of this species on Appendix I of CITES and the USA Endangered Species Act was not based upon any real data on populations or survival status. However, current exploitation levels for most freshwater turtles and tortoises in Myanmar and China require a precautionary approach to any consideration of changing listing status. Clearly, more data are required.

Captive Husbandry. - Both species of Morenia make disappointing pets or captive animals, in that the shell scutes are so thin and vulnerable that, even with careful handling, abrasions occur easily, leading to pathological erosion and perforation of the bony shell. Few specimens have been seen in western zoos, although at least four live specimens in the San Diego Zoo were shown in a photograph in the International Turtle and Tortoise Society Journal (Jul-Aug 1968 p. 38).

Current Research. - No specific research program is directed towards this species, although turtle surveys in Myanmar by J.G. Frazier, P.P. van Dijk, G. Kuchling, personnel of the California Academy of Sciences, others, and myself, as well as the Yunnan market surveys by G. Kuchling, are progressively adding to knowledge of this species. W. McCord maintains a captive group, and P. Prit- 
chard is accumulating series of whole and skeletal voucher specimens of both species of Morenia to use as the basis for morphological comparisons.

Acknowledgments. - Supported by the Centre for Herpetology, Madras Crocodile Bank Trust and Universiti Malaysia Sarawak. A visit to Myanmar was supported by a grant from the People's Trust for Endangered Species. I am grateful to Peter C.H. Pritchard for unpublished observations, and Paul Reef, George Zug, and Gerald Kuchling for photos.

\section{LITERATURE CITED}

ANDERSON,J.1879 ["1878”].Anatomical and Zoological Researches: Comprising an Account of the Zoological Results of the Two Expeditions to Western Yunnan in 1868 and 1875. Vol. I, 984 pp., Vol. II, 29 pp.

BLYTH,E. 1859. Report of Curator,Zoological Department.Proceedings of the Asiatic Society of Bengal 27:267-290.

Boulenger,G.A. 1889. Catalogue of the Chelonians, Rhynchocephalians, and Crocodilians in the British Museum (Natural History). British Museum (Natural History), London, 311 pp.

Buhlmann, K.A., Akre, T.S., Iverson, J.B., Karapatakis, D., MitTERMEIER, R.A., GEORGES, A., RHODIN, A.G.J., vAN DiJK, P.P., AND GibBons, J.W. 2009. A global analysis of tortoise and freshwater turtle distributions with identification of priority conservation areas. Chelonian Conservation and Biology 8(2):116-149.

Cheung, S.M. And Dudgeon, D. 2006. Quantifying the Asian turtle crisis: market surveys in southern China, 2000-2003. Aquatic Conservation: Marine and Freshwater Ecosystems 16:751-770.

DAS, I. 1989. Turtle status scenario in Bangladesh. Turtles and Tortoises Newsletter (4):12-16.

Duméril, A.-M.-C. And BiBron, G. 1835. Erpétologie Générale ou Histoire Naturelle compléte des Reptiles. Vol. 2. Librarie Encyclopedique de Roret, Paris, 680 pp.

Frazier, J.G. 1989. A biologist's visit to Rangoon. Lin Yaung Chi, Rangoon 75:38-43.

Gray, J.E. 1856. Catalogue of Shield Reptiles in the Collection of the British Museum. Part I. Testudinata (tortoises). Taylor and Francis, London, 79 pp.

GraY, J. E. 1869. Notes on the families and genera of tortoises (Testudinidae) and on the characters afforded by the study of their skulls. Proceedings of the Zoological Society of London 1869(1):165-225.

Iverson, J.B. 1992. A Revised Checklist with Distribution Maps of the Turtles of the World. Privately published, Richmond, Indiana, $363 \mathrm{pp}$.

KuCHLING, G. 1995. Turtles at a market in western Yunnan: possible range extensions for some southern Asiatic chelonians in China and Myanmar. Chelonian Conservation and Biology 1:223-226.

Kuchling, G., Lwin, T., AND Min, S.A. 2006. Interview based sur- veys on exploitation and status of endemic river turtles in upper Myanmar and implications for their conservation. Proceedings 2nd International Congress on Chelonian Conservation 18 to 22 June 2003, Senegal. Chelonii 4:254-261.

Maung, W. And Ko Ko, W. 2002. Turtles and Tortoises of Myanmar. Wildlife Conservation Society (Myanmar Program), Yangon. (5), $94 \mathrm{pp}$.

Platt, S.G., Kalyar, and Ko Ko, W. 2000. Exploitation and conservation status of tortoises and freshwater turtles in Myanmar. In: van Dijk, P.P., Stuart, B.L., and Rhodin, A.G.J. (Eds.). Asian Turtle Trade: Proceedings of a Workshop on Conservation and Trade in Freshwater Turtles and Tortoises in Asia. Chelonian Conservation Monographs 2, pp. 95-100.

Platt, S. G., Khaing, S.T., Ko Ko, W., and Kalyar. 2001. Distributional notes on the turtles of western Myanmar. Journal of the Bombay Natural History Society 98:117-120.

Platt, S.G., Ko Ko, W., Lay Khaing, L., Myo Myo, K., Lwin, T., Swe, T., Kalyar, and Rainwater, T.R. 2005. Noteworthy records and exploitation of chelonians from the Ayeyarwady, Chindwin, and Dokhtawady rivers, Myanmar. Chelonian Conservation and Biology 4(4):942-948.

PRITCHARD,P.C.H.1979.Encyclopedia of Turtles.T.F.H.Publications, Neptune, New Jersey, 895 pp.

Sмiтн, M.A. 1931. The Fauna of British India, including Ceylon and Burma. Vol. I. Loricata, Testudines. Taylor and Francis, London, $185 \mathrm{pp}$.

SPINKS, P.Q., ShafFER, H.B., Iverson, J.B., AND McCord, W.P. 2004. Phylogenetic hypothesis for the turtle family Geoemydidae. Molecular Phylogenetics and Evolution 32:164-182.

STRAuch, A. 1862. Chelonogische Studien, mit besonderer Beziehung auf die Schildkrötensammlung der kaiserlichen Akademie der Wissenschaften zu St. Petersburg. Mémoires de l'Académie Impérial des Sciences de St.-Pétersbourg 7(5), 7: 1-196.

Theobald, W. 1868. Catalogue of the reptiles of British Birma, embracing the Province of Pegu, Martaban, and Tenasserim; with descriptions of new or little-known species. Journal of the Linnean Society 10(41):4-67.

Thorbjarnarson, J., Platt, S.G., and Khaing, S.T. 2000. Conservation status of freshwater turtles in Meinmahla Kyun Wildlife Sanctuary and vicinity, Myanmar. Natural History Bulletin of the Siam Society 48:185-191.

\section{Citation Format for this Account:}

DAs, I. 2010. Morenia ocellata (Duméril and Bibron 1835) - Burmese eyed turtle.In: Rhodin,A.G.J., Pritchard,P.C.H., van Dijk, P.P., Saumure, R.A., Buhlmann, K.A., Iverson, J.B ., and Mittermeier, R.A. (Eds.). Conservation Biology of Freshwater Turtles and Tortoises: A Compilation Project of the IUCN/SSC Tortoise and Freshwater Turtle Specialist Group. Chelonian Research Monographs No. 5, pp. 044.1-044.5, doi:10.3854/crm.5.044. ocellata.v1.2010, http://www.iucn-tftsg.org/cbftt/. 